\title{
SIKAP DAN KOMPETENSI GURU PADA PENDIDIKAN INKLUSI DI SEKOLAH DASAR
}

\author{
Yunita Putri \\ Fakultas Psikologi, Universitas Islam Bandung \\ yunitaputrii009@gmail.com \\ Stephani Raihana Hamdan \\ Fakultas Psikologi, Universitas Islam Bandung \\ stephanie.raihana@gmail.com
}

\begin{abstract}
Abstrak
Pemerintah Kota Bandung mengeluarkan kewajiban bagi seluruh sekolah baik negeri maupun swasta untuk dapat menjalankan program pendidikan inklusi. Adanya program pendidikan inklusi ini membuat guru-guru yang berada di Sekolah Dasar Negeri menganggap bahwa pendidikan inklusi menyulitkan karena guru harus dapat memahami kondisi anak berkebutuhan khusus sedangkan mayoritas guru yang mengajar di sekolah dasar negeri ini hanya bergelar PGSD. Namun, hal tersebut tidak terjadi di salah satu sekolah dasar negeri di Kota Bandung, yaitu Sekolah Dasar Negeri Percobaan X yang menjalankan program pendidikan inklusi dari tahun 2017. Di sekolah ini terdapat guruguru yang memiliki sikap positif terhadap pendidikan inklusi yang diwajibkan oleh Pemerintah Kota Bandung dimana guru merasa terbantu dengan adanya program pendidikan inklusi. Guru-guru tersebut juga mau memanfaatkan media lain sebagai bahan ajar untuk siswa berkebutuhan khusus di kelasnya. Penelitian ini menggunakan metode korelasi dengan uji korelasi Rank Spearman. Hasil penelitian menunjukkan adanya hubungan yang cukup antara sikap terhadap pendidikan inklusi dengan kompetensi pada guru.
\end{abstract}

Kata Kunci: Sikap Inklusi, Kompetensi Guru, Pendidikan Inklusi, Sekolah Dasar.

\begin{abstract}
The City Government of Bandung issued an obligation for all public and private schools to be able to run an inclusive education program. The existence of this inclusive education program makes teachers in State Primary Schools consider that inclusive education is difficult because teachers must be able to understand the conditions of children with special needs while the majority of teachers who teach in public elementary schools only hold a PGSD degree. However, this did not happen in one of the public elementary schools in Bandung, namely the Experiment X Public Elementary School which ran an inclusive education program from 2017. In this school there are teachers who have a positive attitude towards inclusive education required by the City Government Bandung where teachers find it helpful to have an inclusive education program. The teachers also want to use other media as teaching material for students with special needs in their class. This study uses the correlation method with the Spearman Rank correlation test. The results showed a sufficient relationship between attitudes towards inclusive education with competence in teachers.
\end{abstract}

Keywords: inclusive attitudes, inclusive education, teacher competences, elementary school. 


\section{PENDAHULUAN}

Sekarang ini, hampir di setiap provinsi di Indonesia sudah tersebar sekolah yang memberlakukan pendidikan inklusi, salah satunya adalah provinsi Jawa Barat khususnya di Kota Bandung. Pada tahun 2015 Pemerintah Kota Bandung mengeluarkan kewajiban bagi tiap sekolah untuk menerima siswa berkebutuhan khusus. Hal itu dilakukan karena Pemerintah Kota Bandung sedang menuju kota pendidikan inklusi. Maka dari itu di mulai dari tahun 2015 seluruh sekolah baik negeri maupun swasta di Kota Bandung tidak boleh menolak siswa berkebutuhan khusus saat penerimaan siswa baru. Jika ada salah satu sekolah yang menolak siswa berkebutuhan khusus maka akan dikenakan sanksi oleh Pemerintahan Kota Bandung (https://news.detik.com).

Sekolah Dasar Percobaan Negeri X merupakan sekolah negeri yang berada di Kota Bandung. Secara khusus sekolah tersebut mengikuti kebijakan inklusi sejak tahun 2017 yang diberikan oleh Pemerintah Kota Bandung. Dari hasil wawancara yang dilakukan kepada tiga guru mengatakan sebelum diadakannya program pendidikan inklusi ini, guru-guru tersebut mengatakan anak berkebutuhan khusus memang sudah ada dari awal dan ditiap tahunnya pasti selalu ada hanya saja jumlahnya tidak seperti di sekolah khusus pada umumnya dan bukan berkebutuhan khusus yang memang nampak secara fisik. Hal itu juga disadari oleh guru-guru dikarenakan saat kegiatan belajar di kelas pasti ada saja anak yang bermasalah dalam belajar.

Akan tetapi karena dasar guru-guru di SDPN X ini adalah PGSD atau mata pelajaran tertentu dan bukan basic di pendidikan khusus maka mereka tidak terlalu memperdulikan keberadaaan anakanak berkebutuhan tersebut. Mereka menganggap bahwa mungkin anak-anak tersebut hanya memiliki masalah dalam belajar saja dan bukan anak berkebutuhan khusus. Guru-guru di SDPN X inipun mengakui bahwa wawasan mereka mengenai pendidikan inklusi dan anak berkebutuhan khusus sangatlah minim bahkan ada juga guru yang tidak mengetahui apa itu pendidikan inklusi.

Guru tersebut mengatakan wawasannya mengenai inklusi adalah bahwa dipendidikan inklusi guru harus selalu ramah dalam arti anak bisa berkembang dengan kekurangannya dan anak yang memiliki kebutuhan khusus tidak boleh dibeda-bedakan dengan anak normal lainnya. Kemudian, guru menganggap bahwa program inklusi juga diadakan untuk dapat membantu anak menjadi percaya diri dengan kemampuannya. Guru mempercayai dengan adanya pendidikan inklusi ini ia dapat terbantu dalam melayani ABK dikelas. Ketika guru dihadapkan dengan anak berkubutuhan khusus dikelas, guru mengatakan mereka memiliki perasaan iba terhadap siswa berkebutuhan khususnya. Guru merasa kasihan ketika melihat siswa berkebutuhan khususnya kurang bisa memahami materi yang diberikan sehingga terkadang guru mencoba menjelaskan kembali materi kepada siswa berkebutuhan khusus. 
Selain itu, guru mencoba mencari referensi dalam penanganan anak berkebutuhan khusus di kelas. Guru juga mengetahui ada media lain yang bisa digunakan dalam proses belajar bagi anak berkebutuhan khusus, seperti pemanfaatan stik eskrim sebagai media berhitung dan penggunaan tutor sebaya sebagai media untuk contoh lebih konkrit agar anak berkebutuhan khusus bisa paham. Guru mengajak anak berkebutuhan khusus untuk berkomunikasi mengenai pemahamannya terhadap mata pelajaran, selain kepada anak guru juga mengajak orang tua untuk berdiskusi mengenai perkembangan anak di sekolah.

Praktek inklusi merupakan tantangan baru bagi pengelola sekolah. Taylor dan Ringlaben (2012) mengatakan bahwa dengan adanya pendidikan inklusi menyebabkan tantangan baru pada guru, yaitu dalam hal melakukan perubahan yang signifikan terhadap program pendidikan dan mempersiapkan guru-guru untuk menghadapi semua kebutuhan siswa baik siswa berkebutuhan khusus maupun non berkebutuhan khusus. Taylor dan Ringlaben (2012) juga menjelaskan mengenai pentingnya sikap guru terhadap inklusi, yaitu guru dengan sikap yang lebih positif terhadap inklusi akan lebih mampu untuk mengatur instruksi dan kurikulum yang digunakan untuk siswa bekebutuhan khusus, serta guru dengan sikap yang lebih positif ini dapat memiliki pendekatan yang lebih positif untuk inklusi. Kemudian penelitian lain yang membahas mengenai sikap guru terhadap inklusi adalah Berry (2006) yang menemukan bahwa kelas inklusi yang efektif bersumber dari keyakinan yang dimiliki guru mengenai kepercayaan dan perlindungan dalam memperbaiki prestasi akademik siswa.

Damayanti, dkk (2016) meneliti mengenai kompetensi pada guru dan ditemukan bahwa domain content kompetensi pada guru dan menunjukkan masih kurang dalam memahami materi pelajaran yang akan disampaikan pada siswa sebagai tugas dan tanggung jawab guru, mencakup pemahaman isi materi dan tujuan belajar. Anna Rozana, dkk (2018) menemukan bahwa guru yang mengikuti pelatihan menunjukkan sikap yang cukup atau tinggi dimana guru sepakat untuk melakukan lebih banyak upaya untuk memperlakukan hal yang sama kepada setiap siswa dan menunjukkan kasih sayang kepada setiap siswa. Berdasarkan hal-hal inilah, penelitian ini disusun dengan tujuan mengetahui hubungan antara sikap dan kompetensi guru mengenai pendidikan inklusi di sekolah dasar.

\section{METODE}

Penelitian mengenai sikap dan kompetensi pada guru dalam pendidikan inklusi di Sekolah Dasar Negeri Percobaan X Kota Bandung yang menggunakan metode korelasi menggunakan . Metode korelasi merupakan penelitian yang dimaksudkan untuk mengukur tingkat hubungan antara dua variabel atau lebih tanpa memanipulasi variabel apapun dengan menggunakan data statistik (Silalahi, 2015). 
Variabel yang dikorelasikan adalah sikap terhadap pendidikan inklusi dan kompetensi guru dalam pendidikan inklusi. Alat ukur yang digunakan untuk mengukur kedua variable dalam penelitian ini adalah berupa kuesioner. Sikap guru terhadap pendidikan inklusi di ukur melalui Multidimensional Attitudes toward Inclusive Education Scale (MATIES) yang disusun oleh Marian Mahat dari Monash University pada tahun 2008. Instrument ini memuat 18 item, dan bertujuan untuk mengukur aspek sikap berdasarkan 3 dimensi yaitu cognitive (kogitif), affective (afektif) dan behaviour (perilaku) dalam konteks pendidikan inklusif. Masing-masing dimensi tersebut diwakili oleh 6 item. Alat ukur ini sudah diuji dan digunakan pada penelitian sebelumnya oleh Muzdalifah dan Billah (2017) dengan hasil uji Validitas dari alat ukur ini merupakan construct validity melalui expert judgement. Alat ukur ini merupakan alat ukur baku yang dibuat oleh Mahat (2008) dan di modifikasi oleh Muzdalifah \& Billah (2017) dengan reliabilitas skor alpha sebesar 0.77 untuk dimensi cognitive, 0.78 untuk dimensi affective, dan 0.91 umtuk dimensi behavioural. Hasil perhitungan validitas dari 18 item, terdapat 15 item yang layak digunakan untuk penelitian dan reliabilitas instrument MATIES adalah 0.96 yang termasuk ke dalam kriteria "istimewa".

Pada variabel kompetensi guru dengan mengacu pada konsep menurut Zulfija,. et al (2013) yaitu kemampuan guru yang memiliki motivasi, pengetahuan, keterampilan, dan memberikan deskripsi hasil belajar anak-anak dalam pendidikan inklusif. Variabel kompetensi guru diukur dengan alat ukur yang dibuat sendiri instrument alat ukur kompetensinya. Dalam membuat instrument dari variable kompetensi ini peneliti mengacu kepada pengertian kompetensi profesional guru dalam pendidikan inklusi serta aspek-aspeknya dari Movkebaieva Zulfija., et al (2013) yaitu seberapa tinggi kemampuan dalam mengajar anak berkebutuhan khusus yang berada dikelas pada guru di SD dalam beberapa aspek sikap, yaitu a) Motivational-Orientation, yakni memiliki motivasi dalam mengembangkan teori dan teknik mengajar kepada anak berkebutuhan khusus dikelas, b) Informational, yakni memiliki pengetahuan dalam memahami anak berkebutuhan khusus, dan c) Operational, yakni memiliki kemampuan keterampilan dalam melibatkan anak berkebutuhan khusus.

Uji try out alat ukur kompetensi ini dilakukan kepada 20 guru SD. Dari hasil uji try out alat ukur Kompetensi Guru, didapatkan hasil bahwa 48 dari 66 item alat ukur dinyatakan valid. Hasil uji reliabilitas alat ukur kompetensi guru sebanyak 48 item valid menggunakan uji Alpha Cronbach didapatkan hasil 0,966. Artinya, diketahui bahwa alat ukur kompetensi memiliki derajatreliabilitas yang luar biasa bagus dan mengindikasikan satisfactory internal consistency reliabilyty, sehingga layak digunakan sebagai instrumen ukuran untuk penelitian.

Penelitian ini adalah penelitian populasi yaitu penelitian yang dilakukan terhadap seluruh populasi yang ditemukan dalam penelitian (Silalahi, 2015).Artinya, seluruh guru yang berada di SDPN X Bandung yang berjumlah 50 orang. 


\section{HASIL DAN PEMBAHASAN}

Perhitungan korelasi antara skor total sikap dengan kompetensi guru dilakukan dengan uji Rank Spearman, dikarenakan data yang didapatkan merupakan data ordinal. Berikut ini adalah hasil uji korelasi Antara Sikap Terhadap Pendidikan Inklusi Dengan Kompetensi Pada Guru Di Sekolah Dasar :

Tabel 1. Korelasi antara sikap dengan kompetensi guru

\begin{tabular}{|c|c|}
\hline $\mathrm{R}$ & Kesimpulan \\
\hline 0,557 & Korelasi cukup, hubungan sedang \\
\hline
\end{tabular}

Berdasarkan tabel di atas, tampak bahwa nilai korelasi (r) adalah 0,557. Dari data di atas, dapat kita simpulkan bahwa terdapat korelasi positif yang signifikan cukup yaitu sebesar $r=0,557$ antara sikap dengan kompetensi guru.Menurut skala korelasi Guillford nilai tersebut termasuk ke dalam kategori korelasi cukup. Artinya, jika sikap positif maka kompetensi guru akan tinggi.

Untuk mengetahui lebih lanjut mengenai hubungan antara komponen-komponen sikap dengan kompetensi guru, dilakukan analisis dengan menggunakan uji Rank Spearman dengan hasil sebagai berikut :

Tabel 2. Hasil Uji Korelasi Aspek-Aspek Sikap dengan Kompetensi Guru

\begin{tabular}{|c|c|c|}
\hline Aspek & Korelasi & Kesimpulan \\
\hline Kognitif & 0,566 & Korelasi cukup, hubungan sedang \\
\hline Afektif & 0,545 & Korelasi cukup, hubungan sedang \\
\hline Perilaku & 0,448 & Korelasi cukup, hubungan sedang \\
\hline
\end{tabular}

Menurut tabel Guillford data di atas termasuk ke dalam kategori cukup antara komponen kognitif, afektif dan perilaku dari sikap dengan kompetensi guru, sehingga memiliki hubungan yang cukup erat antara Sikap dengan Kompetensi Guru. Data aspek tertinggi adalah aspek kognitif dengan aspek perilaku dari Sikap lebih rendah dibandingkan nilai korelasi aspek-aspek Sikap lainnya dengan Kompetensi Guru. Data tersebut menunjukkan hubungan positif antara Sikap dengan Kompetensi Guru yang artinya semakin sikap positif maka kompetensi guru akan tinggi. Untuk mengetahui lebih lanjut mengenai data sikap guru dan kompetensi guru pada pendidikan inklusi dapat dilihat dari tabel tabulasi silang dibawah ini : 
Tabel 3. Tabulasi silang antara Sikap Guru dan Kompetensi Pendidikan Inklusi

\begin{tabular}{|c|c|c|c|c|c|}
\hline & \multicolumn{2}{|c|}{ Kompetensi } & \multirow{2}{*}{ Total } \\
\hline & & & Rendah & Tinggi & \\
\hline \multirow{4}{*}{ Sikap } & \multirow{2}{*}{ Negatif } & Count & 15 & 4 & 19 \\
\hline & & $\%$ of Total & $30,0 \%$ & $8,0 \%$ & $38,0 \%$ \\
\hline & \multirow{2}{*}{ Positif } & Count & 0 & 31 & 31 \\
\hline & & $\%$ of Total & $0,0 \%$ & $62,0 \%$ & $62,0 \%$ \\
\hline \multirow{2}{*}{\multicolumn{2}{|c|}{ Total }} & Count & 15 & 35 & 50 \\
\hline & & $\%$ of Total & $30,0 \%$ & $70,0 \%$ & $100 \%$ \\
\hline
\end{tabular}

Berdasarkan hasil tabulasi silang diatas, diperoleh data bahwa dari 50 guru di Sekolah Dasar Negeri Percobaan Sabang Kota Bandung 31 orang (62,0\%) memiliki sikap positif dan kompetensi tinggi. Kemudian 4 orang (8,0\%) memiliki sikap negatif dan kompetensi tinggi, dan 15 orang (30\%) memiliki sikap negatif dan kompetensi rendah. Data juga menunjukkan tidak ada guru (0\%) yang memiliki sikap positif dan memiliki kompetensi yang rendah. Dengan kata lain hal ini semakin menguatkan bahwa guru yang memiliki sikap positif akan meningkatkan kompetensi guru dalam pendidikan inklusi.

Berdasarkan data yang diperoleh dari subjek sejumlah 50 orang guru SDPN Sabang, didapatkan hasil hubungan yang positif antara sikap dengan kompetensi. Hasil perhitungan korelasi secara keseluruhan antara sikap dengan kompetensi memiliki koefisien korelasi sebesar 0,557 yang menunjukkan bahwa kedua variabel tersebut memiliki korelasi cukup. Artinya, semakin tinggi sikap maka semakin tinggi kompetensi guru di SDPN Sabang Kota Bandung.

Hasil ini sesuai dengan teori yang telah dijabarkan sebelumnya bahwa hubungan positif ditemukan pada guru dalam kompetensi dan sikap mengajar siswa biasa dengan siswa berkebutuhan khusus (Everington, Stevens, \& Winters, 1999). Kemudian hal lain yang menjadi penunjang adanya hubungan positif antara sikap dengan kompetensi adalah pelatihan. Penelitian lain menemukan bahwa pelatihan yang bertujuan untuk merubah sikap mengakibatkan kompetensi yang lebih tinggi (Carroll, Forlin, \& Jobling, 2003). Penelitian di Inggris dan AS menunjukkan bahwa pelatihan guru dapat memiliki efek yang positif bagi kompetensi guru dan sikap (Beacham \& Rouse, 2012; Cheney \& Barringer, 1995).

Selanjutnya, dilakukan uji korelasi antar tiap komponen sikap dengan kompetensi. Komponen kognitif memiliki hubungan positif dengan kompetensi, komponen kognitif ini memiliki hasil korelasi yang paling tinggi dibandingkan dengan kedua komponen lainnya dengan hasil koefisien korelasi sebesar 0,566 yang masuk kedalam kategori cukup. Artinya, guru memiliki keyakinan atau pengetahuan mengenai pendidikan inklusi dan mendidik siswa berkebutuhan khusus. Eagly dan 
Chaiken (1993)komponen kognitif terdiri dari keyakinan atau pengetahuan individu tentang objek sikap. Keyakinan atau pengetahuan guru mengenai mendidik anak berkebutuhan khusus dalam setting inklusif dapat mewakili komponen ini.

Komponen kedua, yaitu afektif memiliki nilai koefisien dengan kompetensi sebesar 0,545 yang berada pada kategori cukup. Artinya, guru mengeluarkan perasaannya ketika mengajar siswa berkebutuhan khusus. Eagly dan Chaiken (1993)komponen afektif mencerminkan perasaan guru tentang mendidik murid dengan kebutuhan khusus. Dari hal tersebut ditunjukkan dengan cara mengajar guru didalam kelas kepada anak berkebutuhan khusus. Guru menunjukkan perasaan mengajarnya kepada anak berkebutuhan khusus dengan memiliki perasaan kasihan kepada anak tersebut serta adanya perasaan kesal ketika anak berkebutuhan khusus tidak memahami apa yang sudah dijelaskan berkali-kali oleh guru.

Komponen terakhir adalah komponen perilaku. Komponen perilaku memiliki korelasi yang paling rendah dengan kompetensi, dibandingkan dengan kedua komponen lainnya. Komponen perilaku memiliki koefisien korelasi sebesar 0,448, nilai tersebut tergolong pada kategori korelasi cukup. Eagly dan Chaiken (1993) komponen perilaku mencerminkan kecenderungan seseorang untuk bertindak terhadap objek sikap dengan cara tertentu. Termasuk juga mengenai pandangan guru tentang cara bertindak kepada anak berkebutuhan khusus di kelasnya. Hal tersebut ditunjukkan dengan cara guru mengikuti pelatihan dan seminar mengenai pendidikan inklusi, serta pandangan guru tentang cara bertindak kepada anak berkebutuhan khusus di kelasnya adalah guru mau mengembangkan potensi yang dimiliki oleh anak berkebutuhan khusus seperti memberikan kepercayaan menjadi ketua kelas atau pemimpin do'a sebelum kegiatan belajar kepada anak berkebutuhan khusus bahwa mereka mampuSistem pendidikan saat ini telah berubah secara drastis dalam beberapa dekade terakhir sebagai pendidikan anak-anak berkebutuhan khusus di sekolah reguler telah menjadi tujuan penting di banyak negara. Perkembangan ini bertujuan untuk menjaga siswa berkebutuhan khusus dalam pengaturan pendidikan reguler yang biasa di sebut dengan istilah 'inklusi' (de Boer, 2009). SDPN menjadi salah satu sekolah yang menjalankan kewajiban penerapan pendidikan inklusi oleh Pemerintah Kota Bandung.

Dalam book review Dipankar Chakravarti mengenai The Psychology of Attitude yang ditulis oleh Alice H. Eagly dan Shelly Chaiken 1993 menjelaskan mengenai sikap. Menurut Eagly dan Chaiken (1993) sikap adalah kecenderungan psikologis yang diungkapkan dengan mengevaluaasi suatu kesamaaan dengan beberapa tingkat suka atau tidak suka. Mereka membangun generalitas definisi ini dengan membandingkannya dengaan analisis konvensional. Sikap adalah "kecenderungan"; tidak selalu bertahan disposisi, mereka dapat dipelajari atau tidak dipelajari dan mereka menyiratkan evaluasi yang mendasari sesuatu yang disetujui atau tidak disetujui kepada objek 
yang menjadi fokusnya. Dalam penelitian dari A. de Boer., et al (2011) menuliskan penjelasan komponen sikap menurut Eagly dan Chaiken (1993) memiliki tiga komponen yaitu 1) Kognitif (Cognitive), Komponen kognitif terdiri dari keyakinan atau pengetahuan individu tentang objek sikap. Keyakinan atau pengetahuan guru mengenai mendidik anak berkebutuhan khusus dalam setting inklusif dapat mewakili komponen ini. 2) Afektif (Affective), Komponen afektif mencerminkan perasaan guru tentang mendidik murid dengan kebutuhan khusus. 3) Perilaku (Behavioral), Komponen perilaku mencerminkan kecenderungan seseorang untuk bertindak terhadap objek sikap dengan cara tertentu. Hal itu termasuk juga mengenai pandangan guru tentang cara bertindak kepada anak berkebutuhan khusus dikelasnya.

Faktor yang Mempengaruhi Sikap Guru terhadap Inklusi menurut Avramidis dan Norwich (2002) dalam Elisa., dkk 2013 memiliki banyak faktor yang mempengaruhi sikap guru, yaitu faktor siswa, guru dan lingkungan sekolah.

Faktor Siswa dimana konsep guru terhadap siswa berkebutuhan khusus biasanya bergantung pada jenis hambatan siswa, tingkat keparahan hambatan siswa, dan kebutuhan siswa akan pendidikan (Clough and Lindsay, 1991 dalam Avramidis and Norwich 2002 dalam Elisa., dkk 2013). Persepsi guru mengenai jenis hambatan siswa dapat dibedakan berdasarkan tiga dimensi, yaitu hambatan fisik dan sensori, kognitif, dan perilaku-emosional yang dimiliki siswa. Dalam kondisi sekolah X tempat diambil data penelitian, keberadaan siswa berkebutuhan khusus dengan tingkat keparahan yang tidak terlalu berat, seperti siswa kesulitan belajar (learning disorders), siswa slow learners, siswa Autis ringan dan tunagrahita mampu didik (mild mental retardation). Jika ada siswa yang membutuhkan penanganan khusus akibat keparahan tinggi akan dirujuk ke sekolah Luar Biasa.

Faktor gender guru juga dapat mempengaruhi sikap guru. Hal ini berkaitan dengan isu gender terhadap inklusi. Beberapa peneliti menemukan bahwa guru perempuan memiliki toleransi yang lebih tinggi dibandingkan guru laki-laki terhadap integrasi untuk siswa berkebutuhan khusus (Aksamit, Morris, and Leunberger, 1987; Thomas, 1985; Eichinger, Rizao, and Strotnik, 1991 dalam Avramidis and Norwich, 2002 dalam Elisa., dkk 2013). Harvey (1985) dalam Avramidis and Norwich dalam Elisa., dkk (2013) melihat bahwa terdapat kecenderungan pada guru perempuan dalam menunjukkan sikap positif terhadap ide mengenai integrasi terhadap anak yang memiliki masalah perilaku dibandingkan guru laki-laki. Namun dalam data menunjukkan bahwa dari 17 orang guru laki-laki dan 33 orang guru perempuan, menunjukkan bahwa 15 orang guru laki-laki (88\%) memiliki sikap positf, sedangkan hanya 16 orang guru perempuan (48\%) yang memiliki sikap positif. Artinya dalam kondisi sekolah dasar dalam konteks Indonesia hal ini menunjukkan perbedaan. Di lokasi penelitian ditelusuri bahwa guru laki-laki lebih sering dijadikan perwakilan sekolah dalam mengikuti pelatihan guru 
sehingga hal ini juga dapat menjadi alasan mengapa guru laki-laki lebih memiliki sikap positif dibanding guru perempuan.

Faktor Usia dan Pengalaman Mengajar juga menjadi faktor lain dalam mempengaruhi sikap guru. Guru yang lebih muda dan dengan pengalaman mengajar yang masih sedikit memiliki sikap yang mendukung terhadap integrasi (Center and Ward, 1987; Berryman, 1989; Clough and Lindsay, 1991 dalam Avramidis and Norwich 2002 dalam Elisa., dkk 2013). Harvey (1985 dalam Avramidis and Norwich 2002 dalam Elisa., dkk 2013) menemukan bahwa terdapat keengganan pada guru yang telah berpengalaman dibandingkan dengan guru pelatihan yang bersedia menerapkan program integrasi kepada siswa berkebutuhan khusus. Hal ini dapat menjadi sebuah alasan bahwa guru baru yang memenuhi syarat memiliki sikap yang positif terhadap program integrasi. Pada data ditemukan bahwa 4 orang guru muda yang bekerja di bawah 1 tahun (100\%) memiliki sikap positif terhadap pendidikan inklusi. Berbeda dengan data 27 orang guru (58\%) yang bekerja diatas 5 tahun memiliki sikap positif dan 19 orang (42\%) memiliki sikap negatif, artinya semakin lama bekerja menunjukkan indikasi perbedaan sikap mengenai pendidikan inklusi.

Tingkat Kelas yang Diajar juga menjadi faktor lain yang meningkatkan sikap positif atau tidak pada pendidikan inklusi. Salvia dan Murson (1986 dalam Avramidis and Norwich 2002 dalam Elisa., dkk 2013) menjelaskan bahwa seiring dengan bertambahnya usia siswa, maka sikap positif yang dimiliki guru akan berkurang dan menunjukkan fakta bahwa guru yang mengajar kelas lebih tinggi lebih memperhatikan pada perbedaan individu siswa. Penjelasan tersebut diperkuat oleh Clough dan Lindsay (1991 dalam Avramidis and Norwich 2002 dalam Elisa., dkk 2013) yang menjelaskan bahwa bagi guru yang lebih memperhatikan materi pelajaran, kehadiran siswa berkebutuhan khusus di dalam kelas mereka menjadi masalah tersendiri dalam praktek pengurusan aktivitas kelas. Hal ini terlihat dari data yang menunjukkan bahwa data wali kelas yang lebih banyak memiliki sikap negatif dengan 17 orang (55\%) memiliki sikap negatif dibandingkan 14 orang (45\%) yang memiliki sikap positif.

Pengalaman Kontak dengan Siswa Berkebutuhan Khusus juga diduga menjadi faktor pembentuk sikap. Sebuah hipotesis mengenai kontak dengan siswa berkebutuhan khusus menyebutkan bahwa sejalan dengan pelaksanaan guru dalam program inklusi, sehingga kontak dengan siswa berkebutuhan khusus semakin dekat, maka sikap yang dimiliki guru semakin positif (Yuker, 1988 dalam Avramidis and Norwich 2002 dalam Elisa., dkk 2013). Namun hal ini masih perlu dibuktikan, karena dalam penelitian menunjukkan kontak dengan siswa berkebutuhan khusus dinyatakan oleh seluruh guru meski demikian hasilnya menunjukkan variasi sikap.

Pelatihan menjadi faktor lain yang mempengaruhi sikap guru yang menarik adalah pengetahuan yang dimiliki mengenai siswa berkebutuhan khusus yang dikembangkan melalui pelatihan yang didapat. Faktor ini dipertimbangkan menjadi faktor penting dalam mempengaruhi sikap guru terhadap 
pelaksanaan kebijakan inklusi. Tanpa rencana untuk memberikan pelatihan kepada guru mengenai pendidikan untuk siswa berkebutuhan khusus, maka akan sulit untuk mengikutsertakan siswa tersebut ke dalam kelas mainstream (Avramidis and Norwich 2002 dalam Elisa., dkk). Berdasarkan hasil wawancara kepada guru, di pertengahan tahun 2018 mereka mengatakan bahwa terdapat program seminar atau workshop mengenai pendidikan inklusi yang diberikan oleh pemerintah Kota Bandung. Kegiatan tersebut diadakan di masing-masing gugus sekolah. Selama diadakan kegiatan tersebut, masing-masing perwakilan guru dari tiap kelas yang berbeda diwajibkan hadir untuk mengikuti kegiatan tersebut. Dari diadakannya kegiatan pelatihan tersebut guru-guru menjadi tahu mengenai pendidikan inklusi dan mau menerima program tersebut. guru menganggap bahwa pendidikan inklusi dapat membantu mereka untuk lebih memahami anak berkebutuhan khusus. Selain itu, guru juga mendapatkan pengetahuan lain mengenai karakteristik dari siswa berkebutuhan khusus.

Keyakinan Guru menjadi faktor lain pembentuk sikap guru. Menurut Jordan, Lindsay, dan Stanovich (1997 dalam Avramidis and Norwich 2002 dalam Elisa., dkk 2013) menjelaskan bahwa guru yang beranggapan bahwa kebutuhan khusus merupakan suatu yang melekat dengan siswa, memiliki cara mengajar yang kurang efektif dibandingkan dengan guru yang beranggapan bahwa lingkungan di sekitar siswa dapat menjadi pelengkap bagi masalah atau hambatan yang dimiliki siswa. Selama kegiatan mengajar dikelas guru yang diwawancara juga mengakui mereka memiliki perasaan iba terhadap siswa berkebutuhan khususnya. Guru merasa kasihan ketika melihat siswa berkebutuhan khususnya kurang bisa memahami materi yang diberikan sehingga terkadang guru mencoba menjelaskan kembali materi kepada siswa berkebutuhan khusus. Tetapi, terkadang gurupun merasa kesal ketika mendapati siswa berkebutuhan khusus dikelasnya tidak paham mengenai materi yang sudah dijelaskan, sehingga guru harus menjelaskannya secara berulang kepada siswa berkebutuhan khusus agar mereka paham

Pandangan Sosio-Politik menjadi faktor yang dapat menjelaskan mengenai sikap guru terkait dengan keyakinan personal (pandangan terhadap politik dan sosial-politik) dan sikap personal (Avramidis and Norwich, 2002 dalam Elisa., dkk 2013). Lebih lanjut, faktor ini juga menjelaskan mengenai keyakinan guru terhadap etnis dan budaya dari anak berkebutuhan khusus dan keyakinan tentang dukungan pemerintah terhadap pendidikan inklusi. Berdasarkan hasil wawancara, guru-guru yang berada di sekolah tersebut awalnya tidak mengetahui diadakannya program pendidikan inklusi di tiap sekolah. Guru-guru tersebut juga dianggap tidak peduli dengan keberadaan siswa berkebutuhan khusus hal itu dikatakan oleh kepala sekolah SDPN X Kota Bandung. Pada tahun 2017, guru mulai dikenalkan dengan program inklusi oleh kepala sekolah. Awalnya kepala sekolah menunjuk salah satu guru untuk dapat mengikuti kegiatan pelatihan dan seminar-seminar. Guru tersebut merupakan salah satu perwakilan yang mengikuti pelatihan dari SDPN Sabang Kota 
Bandung. Kemudian salah satu guru yang menjadi perwakilan untuk mengikuti pelatihan serta seminar tersebut, menjelaskan mengenai pengalamannya selama mengikuti kegiatan dan menjelaskan mengenai pendidikan inklusi kepada guru-guru lain. Selain itu, terdapat pula beberapa guru yang mengikuti kegiatan pelatihan maupun seminar diluar yang tidak diadakan dari sekolah.

Lingkungan Pendidikan menjadi salah satu faktor yang dapat mempengaruhi sikap positif guru adalah ketersediaan dukungan fasilitas di dalam kelas dan level sekolah (Center and Ward, 1987; Myles and Simpson, 1989; Clough and Lindsay, 1991 dalam Avramidis and Norwich 2002 dalam Elisa., dkk 2013). Dukungan yang dimaksud dalam hal ini adalah, sumber daya fisik seperti, perlengkapan mengajar, perlengkapan IT, lingkungan fisik yang mendukung dan lain-lain. Serta sumber daya manusia seperti guru khusus, terapis, kepala sekolah, orang tua dan lain-lain. Kondisi sekolah SD yang menjadi lokasi penelitian meskipun merupakan sekolah percontohan namun dari sisi sarana prasarana dirasakan guru terbatas, khususnya untuk pembelajaran siswa berkebutuhan khusus. Oleh karenanya dalam kegiatan mengajar juga guru di SDPN X Kota Bandung ini mencari referensi mengenai penanganan siswa berkebutuhan khusus. Referensi penanganan yang dicari oleh guru dapat berupa bentuk buku maupun mencari di internet. Kemudian guru juga memanfaatkan media yang ada ketika mengajar dikelas untuk siswa berkebutuhan khusus, seperti memanfaatkan media dengan menggunakan stik eskrim dalam menghitung, memanfaatkan tutor sebaya dalam memberikan contoh yang lebih kongkrit agar siswa berkebutuhan khusus lebih mudah memahami pelajaran.

Guru-guru juga mengajak siswa berkebutuhan khusus di kelasnya untuk berkomunikasi mengenai kegiatan belajarnya baik di sekolah maupun dirumah. Seperti hal apa yang belum siswa pahami mengenai pelajaran di sekolah atau juga menanyakan kegiatan sehari-hari siswa tersebut. Terkadang siswa berkebutuhan khusus tersebutpun menjadikan guru di sekolahnya sebagai tempat cerita mengenai masalah yang dialaminya. Selain dari siswa, guru juga berkomunikasi dengan orang tua siswa agar orang tua mengetahui apa yang menjadi kekurangan anak selama di sekolah serta gurupun memahami cara penanganan yang lebih baik bagi siswa berkebutuhan khusus melalui komunikasi dari orang tua.Guru yang berada di SDPN Sabang Kota Bandung ini, sudah pernah mengikuti kegiatan pelatihan ataupun seminar yang diadakan dari sekolah atau luar sekolah. Beberapa guru mengatakan, program pelatihan yang mereka ikuti dapat membuat guru paham bagaimana kondisi siswa berkebutuhan khusus. Karena dalam kegiatan pelatihan tersebut guru memerankan kondisi menjadi siswa berkebutuhan khusus.

Dalam kaitan sikap dengan kompetensi guru, maka kompetensi guru yang dibahas dalam penelitian ini mengacu pada konsep menurut Movkebaieva Zulfija (2013) yang merupakan seorang Dokter Pendidikan dan Profesor dari Kazakh National Pedagogical mengatakan bahwa kompetensi 
profesional guru dalam pendidikan inklusi adalah guru memiliki motivasi, pengetahuan, keterampilan, dan memberikan deskripsi hasil belajar anak-anak dalam pendidikan inklusif.

Kompetensi pada dasarnya merupakan deskripsi tentang apa yang dapat dilakukan seseorang dalam bekerja, serta wujud dari pekerjaan tersebut dapat terlihat. Dalam UUD Republik Indonesia Nomor 14 Tahun 2005 tentang Guru dan Dosen, dijelaskan bahwa "kompetensi adalah seperangkat pengetahuan, keterampilan, dan perilaku yang harus dimiliki, dihayati, dan dikuasai oleh guru atau dosen dalam melaksanakan tugas keprofesionalan." Menurut Mulyasa, pada hakekatnya standar kompetensi guru adalah untuk mendapatkan guru yang baik dan professional, yang memiliki kompetensi untuk melaaksanakan fungsi dan tujuan sekolah khususnya tujuan pendidikan pada umumnya, sesuai kebutuhan masyarakat dan tuntutan zaman (E. Mulyasa).

Menurut Movkebaieva Zulfija (2013) dalam penelitiannya mengungkapkan bahwa komponen kompetensi profesional guru dalam pendidikan inklusi terdapat tiga komponen, yaitu komponen motivasional-orientation, informasional dan operasional.

Komponen Motivational-Orientation, yakni adanya motivasi yang dimiliki berkaitan dengan pendidikan inklusif, memiliki orientasi dan nilai-nilai pribadi, memiliki toleransi, kurangnya prasangka, fokus kepada komunikasi, serta mengembangkan teori dan teknik pendidikan inklusif, dengan kriteria komponen dalam 4 jenis kriteria dari kompetensi guru dalam pendidikan inklusif, yaitu a) Adanya motivasi untuk pelaksanaan pendidikan inklusif, b) Jumlah orientasi dan nilai-nilai pribadi guru, c) Ciri khas guru: toleransi, kurangnya prasangka, fokus pada komunikasi dan interaksi dan d) Perlunya pengembangan teori dan teknik pendidikan inklusif.

Komponen Informational, yaitu memiliki pengetahuan-pengetahuan mencakup pengetahuan teoritis, pengetahuan teknologi dan keterampilan desain-konstruktif. Informational memiliki 3 jenis kriteria dari kompetensi guru dalam pendidikan inklusif, yaitu : a) Pengetahuan teoritis: pengetahuan hukum, pemahaman psikologis, hukum pendidikan, dan kekhasan perkembangan usia dan kepribadian anak-anak disabilitas, b) Pengetahuan teknologi: bentuk, teknologi, alat, metode, kondisi pendidikan inklusif yang efektif untuk anak-anak, c) Keterampilan desain-konstruktif: pemahaman tentang bagaimana merancang, menyesuaikan, memperkirakan, menilai efektivitas pendidikan inklusif.

Komponen terakhir yaitu Komponen Operational yaitu menguasai keterampilan dalam melibatkan anak-anak berkebutuhan khusus, mencakup keterampilan strategis, kemampuan proyek, kemampuan komunikasi dan kemampuan konstruktif. Komponen Operational memiliki 4 jenis kriteria dari kompetensi guru dalam pendidikan inklusif, yaitu : a) Keterampilan strategis: penguasaan keterampilan penetapan tujuan, pemilihan organisasi yang optimal dan evaluasi pekerjaan pendidikan dengan anak-anak disabilitas dalam pengembangan pendidikan inklusif, b) Keterampilan proyek: 
kemampuan untuk merancang dan mengimplementasikan proses pendidikan bersama anak-anak disabilitas dan anak-anak dengan perkembangan normal, c) Keterampilan komunikasi: kemahiran menerapkan berbagai metode interaksi pedagogis antara semua mata pelajaran dari proses pedagogis pendidikan inklusif untuk anak-anak dan d) Keterampilan konstruktif : kemampuan untuk menciptakan lingkungan perkembangan dalam lingkungan pendidikan inklusif dan menggunakan sumber daya dan kemampuan organisasi pendidikan untuk anak-anak disabilitas

Pada data kompetensi guru di SDPN X yang menjadi lokasi penelitian menunjukkan bahwa 35 orang guru (70\%) memiliki kompetensi guru yang tinggi sedangkan hanya 15 orang (30\%) guru saja yang memiliki kompetensi guru yang rendah. Dengan kata lain kompetensi guru di sekolah percontohan ini memiliki kompetensi yang terlatih dalam mendidik siswa baik reguler maupun siswa berkebutuhan khusus. Pelatihan yang diberikan pada guru-guru sekolah melatih mereka memiliki kompetensi yang tinggi.

\section{PENUTUP}

\section{Simpulan}

Berdasarkan hasil penelitian, maka dapat disimpulkan terdapat hubungan yang cukup erat antara sikap terhadap pendidikan inklusi dengan kompetensi pada guru pada sekolah dasar percontohan. Dari analisa pembahasan dapat disimpulkan bahwa faktor pelatihan pendidikan inklusi yang memberikan pemahaman, pengetahuan dan keterampilan terkait pendidikan inklusif dapat menguatkan sikap positif guru sehingga kompetensi guru meningkat dalam melaksanakan pendidikan inklusi di sekolah.

\section{Saran}

Dari data yang diperoleh pentingnya pelatihan pendidikan inklusi yang komprehensif perlu dilakukan untuk meningkatkan baik pengetahuan hingga adanya perubahan perilaku. Pelatihan yang saat ini dilakukan lebih banyak mengarah ada perubahan wawasan mengenai pendidikan inklusi dan belum optimal dalam aspek perilaku. Diharapkan perlunya penyusunan pelatihan pendidikan inklusi yang lebih komprehensif untuk meningkatkan perubahan perilaku langsung. Selain itu juga pelatihan tidak diberikan secara merata pada seluruh guru di sekolah, sehingga diharapkan di masa depan pelatihan pendidikan inklusi dapat diterapkan pada seluruh guru, khususnya wali kelas yang memegang langsung siswa sekolah dasar secara intens. Adanya indikasi fasilitas sekolah yang belum memfasilitasi pendidikan inklusi juga perlu menjadi perhatian bagi dinas terkait. 


\section{DAFTAR PUSTAKA}

Acharya, B. 2010. Questionnaire Design. Central Department of Population Studies Tribhuvan University.

Alkharusi Hussain, S. A. 2012. Educational Assessment Attitudes, Competence, Knowledge, and Practices: An Exploratory Study of Muscat Teachers in the Sultanate of Oman. Muscat; Sultan Qaboos University.

Chakravati, D. 2015. Journal of Marketing Research. American Marketing Association.

Chris Forlin, C. E. 2011. The Sentiments, Attitudes, and Concerns about Inclusive Education Revised (SACIE-R) Scale for Measuring Pre-Service Teachers' Perceptions about Inclusion. Exceptionality Education International; Hongkong, Canada, India, United States.

Damayanti T, \& Hamdan, S. 2016. Deskripsi Tentang Kompetensi Conten Guru Didalam Proses Pembelajaran Inklusi Pada Guru Sd Negeri Di Kota Bandung. Bandung; Universitas Islam Bandung, Fakultas Psikologi.

de Boer, A. P. 2011. Regular Primary Schoolteachers' Attitudes Towards Inclusive Education: A Review of The Literature . Departement of Special Education. University of Groningen, The Netherlands. Pedagogical Inclusive .

Elisa, S. 2013. Sikap Guru Terhadap Pendidikan Inklusi Di Tinjau Dari Faktor Pembentuk Sikap. Surabaya: Universitas Airlangga Fakultas Psikologi dan Pendidikan.

Muzdalifah, F, \& Billah H. Z. 2017. Pengaruh Efikasi Guru Terhadap Sikap Guru Terhadap Pendidikan Inklusi di SD Negeri Inklusif Di Jakarta. Jakarta; Universitas Negeri Jakarta.

Firdaus, E. 2010. Pendidikan Inklusi dan Implementasi di Indonesia. Bandung; Universitas Pendidikan Indonesia.

Garnida, D. 2009. Studi Tentang Peran Dan Fungsi Sistem Dukungan Dalam Penyelenggaraan Pendidikan Inklusif Di Kota Bandung. Bandung; Departemen Pendidikan Nasional Pusat Pengembangan Dan Pemberdayaan Pendidik Dan Tenaga Kependidikan Taman Kanak-Kanak.

Garnida, D. 2015. Pengantar Pendidikan Inklusif. Bandung PT Refika Aditama.

H, N. 2012. Psikometri (Aplikasi dalam Penyusunan Instrumen Pengukuran Perilaku). Bandung; Universitas Islam Bandung.

Ineke M Pit-et Cate, M. M.-S. 2018. Promoting Inclusive Education: The Role of Teacher' Competence and Attitudes. Insights into Learning Disabilities 15 (1), 49-63.

Latifah, E. 2015. Persepsi Orang Tua Reguler Terhadap Pendidikan Inklusif Di Sdn Bulukerto 2 Batu. Malang; Universitas Muhammadiyah Malang.

Mahat, M. 2008. The Development Of A Psychometrically-Sound Instrument To Measure Teachers' Multidimensional Attitudes Toward Inclusive Education. Monash University; International Journal Of Special Education. 
Maulipaksi D, L. A. 2017. Sekolah Inklusi dan Pembangunan SLB Dukung Pendidikan Inklusi. Jakarta; Kementrian Pendidikan dan Kebudayaan.

Movkebaieva Zulfija, O. I. 2013. The Professional Competence Of Teachers In Inclusive Education. Kazakhastan; Kazakh National Pedagogical University.

Norwich, E. A. 2002. Teacher's Attitudes Towards Integration/Inclusion. A Review Of The Literature United Kingdom; University of Bath University of Exeter.

Nurmatari, A. 2015. Ridwan Kamil Mewajibkan Sekolah di Bandung Terima Siswa Berkebutuhan Khusus. Jakarta: Detiknews https://news.detik.com/berita-jawa-barat/d-3053463/ridwankamil-wajibkan-sekolah-di-bandung-terima-siswa-berkebutuhan-khusus.

O.B Bamigboye, O. B. 2013. Nigeria University Of Agriculture. Nigeria; University Of Agriculture.

Padmasari, D. F. 2012. Analisis Kebijakan Pendidikan Inklusif Bagi Anak Hiperaktif Di Sekolah Dasar Kabupaten Magetan. Malang; Universitas Muhammadiyah Malang.

Rudiyati, S. 2011. Potret Sekolah Inklusif di Indonesia. Seminar Umum "Memilih Sekolah Yang Tepat Bagi Anak Berkebutuhan Khusus”. Yogyakarta: Dosen Jurusan PLB FIP UNY.

Rustanti, Y. M. 2017. Analisis Kompetensi Pedagogik Pada Guru Kelas Di Sekolah Dasar Negeri Dadaprejo 1 Batu. Malang; University of Muhammadiyah Malang.

Safira, A. 2016. Pendidikan Inklusi. Jakarta: Binus University Faculty Of Humanities. http://eprints.ums.ac.id/48120/2/BAB\%20I.pdf.

Setianingsih, E. S. 2018. Penerimaan Dan Sikap Guru Terhadap Keberadaan ABK DiSekolah. Semarang;Universitas PGRI Semarang.

Sidiq, Z. R. 2017. Pembelajaran Kebutuhan Pendidikan Khusus. Bandung; Universitas Pendidikan Indonesia.

Sofiah Bastari S, W. R. Tanpa Tahun. Gambaran Sekolah Inklusif Di Indonesia Tinjauan Sekolah Menengah Pertama. Jakarta Kementerian Pendidikan dan Kebudayaan Pusat Data dan Statistik Pendidikan dan Kebudayaan.

Syafi'i, R. 2012. Evaluasi Pembelajaran Anak Berkebutuhan Khusus Di Sekolah Dasar Penyelenggara Pendidikan Inklusif Kota Tasikmalaya. Bandung; Universitas Pendidikan Indonesia.

Widdy, N. P. 2016. Kompetensi Guru Berdasarkan Jenis Kelamin, Usia, Pengalaman Mengajar dan Tingkat Pendidikan. Yogyakarta; Universitas Sanata Dharama.

Wiyono, B. 2011. Pendidikan Inklusif (Bunga Sampai Pemikiran Educational For All). Malang; Universitas Negeri Malang, Program Studi Bimbingan dan KonselingDe Porter, Bobbi dan Hernacki, Mike. 1992. Quantum Learning. Membiasakan Belajar Nyaman dan Menyenangkan. Terjemahan oleh Alwiyah Abdurrahman. Bandung: Penerbit Kaifa. 